\title{
Proposed Marketing Strategy for Commercial Medium \& Light Turboprop Aircraft in Indonesia (Case Study: PT. Dirgantara Indonesia)
}

\author{
Agnes Grace Florence, Atik Aprianingsih, Heber Mey Fredryk Panjaitan, Dina Rachma Febrina, and \\ Bayu Aji Prakoso \\ School of Business \& Management, Institut Teknologi Bandung, Bandung \\ e-mail: agnes.grace@sbm-itb.ac.id
}

\begin{abstract}
National defense is all efforts to maintain the national sovereignty, the territorial integrity of a state and the safety of all nations from threats and disruption to the integrity of the state. It is important because the strength of the country lies in its defense, which will affect national development. As a national defense industry, PT. Dirgantara Indonesia (PT DI) is responsible for providing defense equipment for its users; Ministry of Defense and the Indonesian National Armed Forces. The product sales contribute $61,79 \%$ to the total sales revenue for company. However, this percentage is still far as the targeted then PT DI needs another strategies in order to maintain its business. Since the last 5 years, PT DI only focused on military products. On the other hand, PT DI cannot depend only on sales from military product because there is still high possibility contract cancellation due to changes the policy, the products do not meet as the requirements, or lack of budget. The main problem faced by PT DI is decreasing percentage of aircraft sales. Therefore PT DI needs expanding their market by producing N219 and N245 aircraft for commercial configuration as one of the company's development methods. However to produce new products, PT DI will face main problem that is how PT DI enters the commercial market to increase sales of $\mathrm{N} 219$ and $\mathrm{N} 245$. The analysis using both internal and external analysis. The company's internal analysis consists of STP analysis and Marketing Mix. Moreover for external analysis, the authors using PESTEL analysis, Porter's 5 forces analysis, competitor analysis, and customer analysis. It is found different perspectives between current marketing mix of PT DI with customer perspectives related to N219 and N245 aircrafts. The existing marketing mix is not optimal and effective. The new propose marketing strategy which consist of product, price, place, and promotion are need to overcome this issue.
\end{abstract}

Keywords-Marketing Strategy, Turboprop, Aircraft Manufacturer, Commercial Market.

\section{INTRODUCTION}

$\mathrm{I}_{\mathrm{o}}^{\mathrm{N}}$ NDONESIA'S national defense is managed by the Ministry of Defense. To support these needs, the state needs an adequate defense budget. At present the budget of the Defense Ministry of the Republic of Indonesia has increased from year to year as shown in the Figure 1.

In the 2019 APBN, the budget for the Ministry of Defense of Indonesia is IDR 108.36 trillion or $4.4 \%$ from total government expenditure with amount IDR 2,461.1 trillion. The Ministry of Defense budget is the second largest after the
Ministry of PUPR budget with amount IDR 110.7 trillion. The biggest budget of the Ministry of Defense this year was for the implementation of the management and operational plan of the land dimension IDR 37.49 trillion and for the sea dimension IDR 11.16 trillion, and infrastructure improvement program for the Ministry of Defense IDR 15.37 trillion.

Indonesia is a maritime country which consist of thousand islands. The geographical condition of the archipelago shows how important the strategic defense industry to protect the defense of the Republic of Indonesia on land, sea and air. For air dimensions, this strategic responsibility is very important for Indonesian Aerospace (also known as PT Dirgantara Indonesia) as an aircraft manufacturer that is able to connect from one island to another in a short and effective time.

PT. Dirgantara Indonesia (English name: Indonesian Aerospace Inc.) is the first and the only Indonesia aircraft producer in the Southeast Asia region. This company is owned by the Republic of Indonesia.

PT DI was established on April 26, 1976 under the name of PT. Industri Pesawat Terbang Nurtanio and BJ Habibie as President Director. The Nurtanio Aircraft Industry then changed its name to the Industri Pesawat Terbang Nusantara (IPTN) on October 11, 1985. After being restructured, IPTN then changed its name to Dirgantara Indonesia on August 24, 2000 .

Dirgantara Indonesia not only manufactures various aircraft but also helicopters, weapons, provides training and maintenance services for aircraft engines. Dirgantara Indonesia is also a sub-contractor for major aircraft industries in the world such as Boeing, Airbus, General Dynamic, Fokker and others. Dirgantara Indonesia once had up to 16.000 employees but due to economic crisis that hit Indonesia, Dirgantara Indonesia did early retirement its employees to around 4.000 people.

PT DI is led by a President Director, Elfien Goentoro, who has five Directorate under his supervision those are Directorate of Finance, Directorate of General Affairs \& Human Capital, Directorate of Commerce, Directorate of Technology \& Development, and Directorate of Production PT DI has four business cores, there are Aircraft, Aero Structure, Aircraft \& Engine Services, and Technology \& Development. Detail explanation regarding each business core as follows: 
The $1^{\text {st }}$ International Conference on Business and Engineering Management (IConBEM)

February $1^{\text {st }} 2020$, Institut Teknologi Sepuluh Nopember, Surabaya, Indonesia

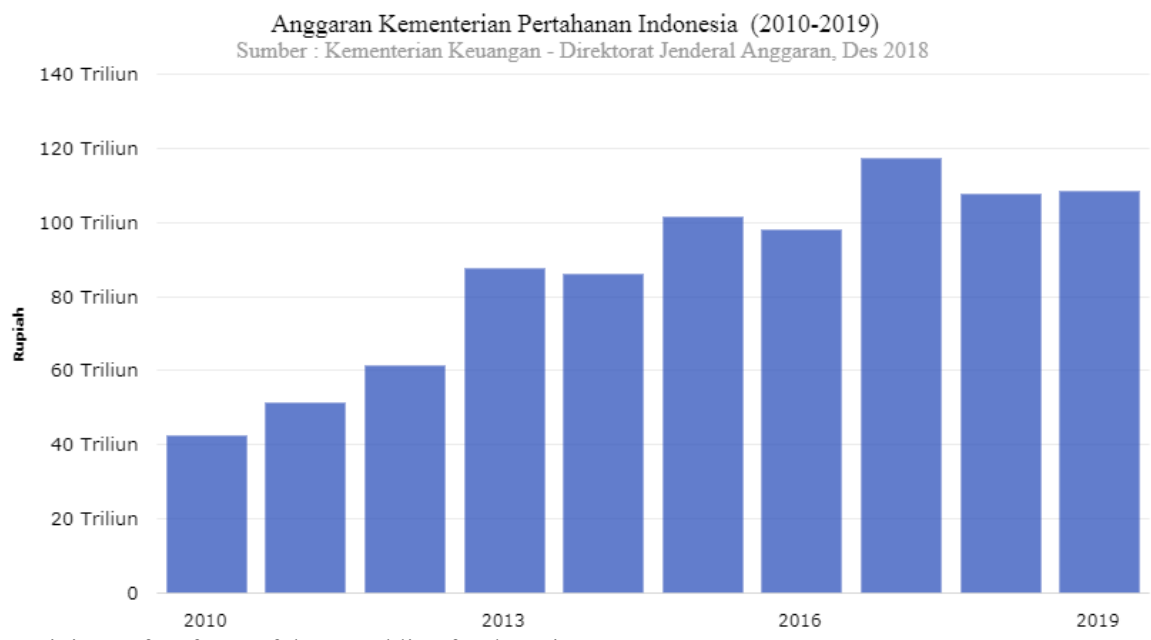

Figure 1. Budget for the Ministry of Defense of the Republic of Indonesia.

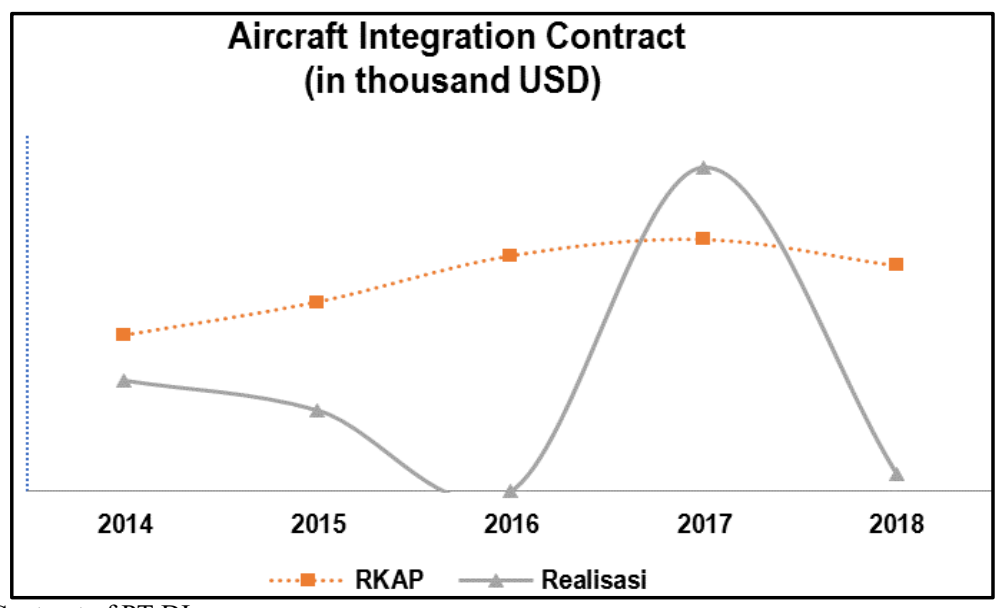

Figure 2. Aircraft Integration Contract of PT DI .

\section{a. Aircraft}

PT DI produces various types of aircraft to fulfill the needs of civil airlines, military operators and specific missions. Through many years in aircraft design, PT DI has become proficient in, capable of designing new aircraft and changing the aircraft's system configuration, and structure for specific mission purposes such as maritime patrol, surveillance and coast guard.

\section{b. Aero Structure}

PT DI provides design and manufacture tools and jigs, metal forming/fabricated part, composite components, bonding components, etc. Also, they are experienced in subassembly, major assembly, and final assembly.

c. Aircraft \& Engine Services

Not only those products, PT DI also provides MRO (Maintenance, Repair \& Overhaul) services for fixed wing and rotary wing products which have been delivered to the Republic of Indonesia Defense stakeholders such as Ministry of Defense of the Republic of Indonesia, Indonesian National Armed Forces consisted of Army, Navy, and Air Force. It is included technical support, technical publications in form of documents and manual, training for pilot and mechanic.

\section{d. Technology \& Development}

PT DI has wide technical capability particularly in the field of engineering, simulator technology, product development, system integration, defense and safety maintenance system, transportation, etc.
Defense Industry and Indonesian National Armed Forces have strategic planning which requires a variety of defense equipment. Basically, PT DI has to prepare all air defense equipment such as aircrafts and helicopters. Defense Industry and Indonesian National Armed Forces need various types of aircraft and helicopters according to their use in strategic planning. As user, technically they have special technology specification requirements in line with the strategic planning for the aircraft and helicopters. Not all types of aircraft and helicopters are able to be supplied by PT DI due to the limited of resources and ability of mastery in aerospace technology. PT DI only capable in supply fixed wing aircraft which is classified as light and medium turboprop.

Law Number 16 of 2012 on the Defense Industry guarantees direct appointment of PT DI as the tender for procurement of defense equipment. It applies if the aircraft or helicopter meet the technical specifications and operation requirements by the user. It is stated in Law Number 16 of 2012 Article 43 paragraph 1 and 2. If PT DI are not able to fulfill technical specifications and operation requirements, the customer has the right to do open auction involving the international defense industry. In this case, PT DI is in charge as receiver an offset or ToT (Transfer of Technology) where the amount are regulated in Article 43 paragraphs 5 and 6 of Law Number 16 of 2012.

If this case continues, PT DI cannot obtain the contract and it can lead to decreasing percentage in the sales of aircraft 
The $1^{\text {st }}$ International Conference on Business and Engineering Management (IConBEM)

February $1^{\text {st }} 2020$, Institut Teknologi Sepuluh Nopember, Surabaya, Indonesia

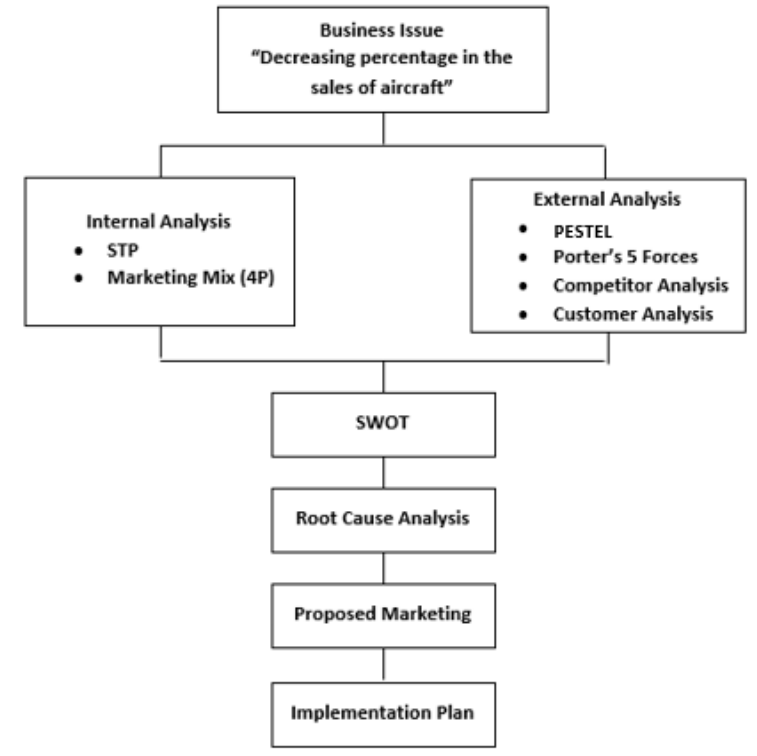

Figure 3. Research Framework

which wider the gap between RKAP and the realization. Data related RKAP and realization of aircraft integration in 2014 2018 are shown as in Figure 2.

Based on this background, PT DI need to seek another strategy to sustain their business and not depending only on military market. This research focusing on market opportunity of Indonesia's aerospace industry and the marketing strategy for PT DI in sustaining the business.

For PT DI case, the researcher will focus on sales of commercial aircrafts these are N219 and N245 aircrafts. The reason is because PT DI do not have long-term contracts and lost the tender which led to decreasing percentage of military aircraft sales. So PT DI needs other marketing strategic plans to reduce the dependency on military aircraft by changing their marketing focus in to enter domestic and commercial aircraft market.

\section{METHOD}

Based on the research framework in Figure 3, the business issue we need to discuss is decreasing percentage in the sales of aircraft. Therefore, we need to do a business analysis to solve the problem. The analysis using both internal and external analysis.

The researcher using primary and secondary data. For primary data, the researcher will use individual personal interviewing as consumer analysis. Personal interviewing is one of the best methods for gathering information quickly, and it provides greater flexibility. Interviewers can guide interviews, explain difficult questions, and explore issues as the situations requires. Interview addressing almost any marketing questions or decisions can be conducted by phone or mail, in person, or online [1]. In this research, the researcher select population members who are good prospects for accurate information. As gathered information from PT DI, the researcher found three potential customer in commercial markets, there are Aviastar, Trigana Air Service, Pelita Air Service, Dimonim Air and Gatari Air Service.

For secondary data, the researcher will use both internal and external analysis which consisted of STP analysis, marketing mix (4P), PESTEL analysis, Porter's 5 Forces, and competitor analysis. Source of data collected by books, journals, company reports, and online websites. Internal analysis aims to identify a number of strengths and weaknesses that are contained in the company's internal business resources and processes. In the other hand, external analysis is all factors outside the company which influence the company. Analysis of the external environment needs to be done to identify opportunities and threats faced by an organization which it can generate strategies to create advantage from those opportunities and avoid or minimize the impact of potential threats that may arise.

\section{RESULTS AND DISCUSSION}

Numerals of five or more digits are grouped in three-digit blocks by spaces, e.g. 12,345 (if written in English) or 12.345 (if written in Bahasa Indonesia). Pay attention a significant figure and avoid an unnecessary long digit number.

\section{A. Internal Analysis}

Analysis of the company's internal environment aims to identify a number of strengths and weaknesses that are contained in the company's internal business resources and processes. Internal business processes and resources are said to have power if those internal business processes and resources have the capability (capability) that will create distinctive competencies so that the company will gain a competitive advantage.

\section{1) STP Analysis}

This analysis helps the company to do target marketing. Companies are limited to serve all market segments so they need to identify which market they can serve better and more profitably.

\section{a. Segmentation}

Segmentation of PT DI will be explained as follows:

- Geographic : In this attribute, it can be determined geographically market segmentation for PT DI which is located mostly in Asia, Africa and Australia, particularly in the archipelago area.

- Demographic : Civil and military flight operators / government (Military Civil Government/MCG) for medium and small class turboprop aircraft, seat capacity 12-60 passengers.

- Psychographic: Business development of PT DI opens a new segment for civil operators for short-haul and midrange flights in the turboprop aircraft. In addition, another segment is in the area that has an airport or air strip with a short runway length which is jet-engined aircraft cannot operate.

\section{b. Targeting}

The market areas to be targeted for the marketing of PT DI's aircraft is the domestic market. In this case, the company choses civil government and civil passenger as the target for PT DI.

The potential market for civil government is quite large because of the demands of aircrafts and helicopters for Indonesian Airlines such as Aviastar, Trigana Air Services, Pelita Air Services, Dimonim Air, and Gatari Air Service. Not only that, the market potential for civil passenger is also quite large, in particular for inter-island flights and pioneer flights in remote areas in Indonesia where transportation access is still difficult. 
The $1^{\text {st }}$ International Conference on Business and Engineering Management (IConBEM)

February $1^{\text {st }} 2020$, Institut Teknologi Sepuluh Nopember, Surabaya, Indonesia

\section{c. Positioning}

N219 and N245 are positioned as commercial aircraft with the positioning "Robust aircraft in remote area and cost competitive (both selling price and operation cost)," means the aircraft is created to welfare people who live in remote areas with minimal prices. N219 is positioned as solution for pioneer area which connecting small area of Indonesia in order to accelerate growth in remote areas. N219 is considered as affordable aircraft with smaller capacity. Furthermore, N245 is positioned as a flight solution for short distance and VIP routes. Thus, N245 is perceived for exclusive aircraft with larger capacity.

\section{2) Marketing Mix (4P) Analysis}

This analysis is set of tools possessed by the company to influence the customer for its product. It helps the company to describe marketing options in order the product can meet the need or demand of customers.

a. Product

The actual product is tangible which means it can be touched or physical product. The actual product considered as what people think under the generic banner of product. N219 and N245 are the commercial aircrafts manufactured by PT DI with a good quality. N219 is designed for 19 passengers with the largest cabin cross section of its class, the engine is proven and efficient, advanced avionics system, fixed tricycle landing gear, and wide cargo door to make it easier to change aircraft configuration. Thus, N245 is designed to provide the advantages to the operators from technical and economic aspects with seat capacity for 30-60 passengers.

The augmented product is the non-physical thing of the product. It consists of some added value which the customer might or might not pay the surcharge. When customer buy N219 or N245 aircraft, the augmented product are the warranty, technical publication, training, and technical assistance.

b. Price

Price of N219 and N245 are set using cost based pricing strategy because they set the price after producing a product. The selling price of aircrafts is determined by the prices prevailing for the same class in Indonesian market and it has to be relatively cheaper and has a resale value. Customers in the commercial market are too price sensitive so PT DI must offer products relatively cheaper in order to be accepted but still profitable. But in contrast, PT DI selling prices is high due to the high rate of tax $(65 \%$ tax will be charged to the customers) so the product is less competitive than the competitors. This condition happened because of PT DI still using import raw materials from overseas. PT DI sells N219 with amount USD 6 million and for N245 is USD 19 million with annual increase $4 \%$ per year. If there is no regulation regarding tax policy, the selling price of PT DI aircraft can be the same or more competitive than its competitors.

c. Place

Customer can look for the product both online and offline store. For the offline store, PT DI is located in Jalan Pajajaran No. 154 Bandung 40174 as shown in figure 2.1. It is place for production, engineering and management of PT DI. Located in strategic area, makes potential customer easy to get to the location with or without public transportation. Also they provide a large parking area with high security system. PT DI In terms of marketing commercial aircraft, PT DI utilizes distribution channels through relevant state stakeholders such as. Not only that, PT DI provides online media so the customer can access through their website. The website consists of information regarding PT DI's portfolio business such as products description, features, configuration, and performance.

\section{d. Promotion}

To build a good relationship between customer and seller, company have to communicate their value propositions to customer. People who work in PT DI still have mindset noncommercial because all this time their mindset are limited to military products so the company need integrated tools to fulfill this goal. Those promotion tools will be explained as follows:

\section{- Advertising}

Since the product has a very specific market, the most effective advertising for commercial aircraft is through advertorial or article in a magazine, flyer, brochure, booklet, and leaflet. These tools especially shared in exhibition or guest visitation as information map for potential customer. One of the familiarities from defense industry marketing communication is those tools should contain detail fact sheets and technical information. Which is usually can only be understood for certain circles only (i.e.: engineers).

\section{- Personal Selling}

The company's sales representative presents in order to make sales and build customer relationship. It includes of presentations, trade shows, and incentive programs. Both local and global exhibitions are the vital marketing tools for PT DI. Exhibition provides an ideal opportunity to showcase the product and services to a highly targeted audience especially N219 and N245.

\section{- Public Relations}

PT DI promotes the products by corporate communications, media relations, event management, and digital platform optimization (owned and earned media) through Website, Instagram, Twitter, and Facebook. People can access those media and get the information needed easily through the website.

\section{- Direct Marketing}

Direct marketing is direct approach to the target customer for obtaining a quick response from the audience. For example direct response $\mathrm{TV}$, catalogs, the Internet, and mobile marketing

\section{B. External Analysis}

Analysis of the external environment needs to be done to identify opportunities and threats faced by an organization which it can generate strategies to create advantage from those opportunities and avoid or minimize the impact of potential threats that may arise. PT DI is concerned about changes in the external environment, because this can be an opportunity to develop strategies to deal with market changes that also result in changes in product requirements.

\section{1) Industry Overview}

Turboprop aircraft with small capacity play a key role in developed country as a substitute for a rail or road transportation. While other developing countries have wellprepared rail and road transportation system for short haul 
The $1^{\text {st }}$ International Conference on Business and Engineering Management (IConBEM)

February $1^{\text {st }} 2020$, Institut Teknologi Sepuluh Nopember, Surabaya, Indonesia

Table 1.

Commervial Turboprop Manufacturers Market in Indonesia

\begin{tabular}{ll}
\hline \multicolumn{1}{c}{ Manufacturer } & \multicolumn{1}{c}{ Country } \\
\hline ATR & France and Italy \\
Bombardier Aerospace & Canada \\
Viking Air Ltd. & Canada \\
CASA & Spain \\
Indonesia Aerospace & Indonesia \\
\hline \hline
\end{tabular}

travel, Indonesia has no alternative for short haul transportation besides air transportation. It is the reason turboprop market business is become interesting in Indonesia. Manufacturer of turboprop aircraft that currently market in Indonesia is described in Table 1.

\section{2) PESTEL Analysis}

Aerospace industry is concerned about changes in the external environment, because this can be an opportunity to develop strategies to deal with market changes that also result in changes in product requirements. Current predictions are that the environment for all organizations will become even more uncertain with every passing year.

a. Political

From the 9 missions of the new Cabinet Government, there are 2 missions including those that affect commercial aircraft business policy. The first mission is a productive, independent and competitive economic structure in which there are several action programs that support the acceleration of the commercial aircraft businesses, one of which is to increase the added value of infrastructure utilization. This action program supports the use of the aircraft which was designed as a very suitable aircraft to serve pioneering flights according to Indonesia's geographical conditions in accelerating the equitable development of infrastructure, growing new economic centers and integrating infrastructure development.

Another mission in the new cabinet government that supports the aerospace industry is equitable and equitable development. One of the related action programs in it is to develop regional economic potential for equitable regional development. Utilization of the use of aircraft as integrated connectivity infrastructure with the development of regional leading economic sectors is a factor that makes aerospace industry optimistic about its commercial aircraft business.

b. Economic

Changes in world oil prices greatly affect the aerospace industry. The world oil price which reached above USD 70 per barrel in the second half of 2018, then gradually dropped to USD 60 per barrel in 2019. Rising world oil prices result in rising airline ticket prices. This is very common because the fuel cost component in the direct cost structure of an aircraft is very dominant.

The economic growth rate (GDP) is one of the factors affecting air traffic growth. This is because the magnitude of the economic growth rate is closely related to passenger growth rates or RPK (Revenue/Seat Passenger Kilometer). The amount of air traffic growth is always higher than the rate of economic growth.

Developing countries have higher economic growth rates compared to developed countries, therefore more and more people are traveling in these countries, both with economic motives and not. In addition, the number of middle class and upper middle class people in developing countries is increasing. The middle and upper middle class are carrying out more trips, particularly air traffic in developing countries is higher compared to other countries. Turboprop manufacturers seized this opportunity by presenting small and middle sized turboprop aircrafts. The upper middle class people tend to choose the two commercial aircraft products as modes of transportation because they have shorter travel times in connecting regional regions of Indonesia compared to the modes of sea, land and rail transportation.

c. Sociocultural

Millennial generation is a generation that considers themselves have the right to travel or travel. No wonder then this $M$ generation later became one of the pillars of the modern tourism industry. The research results of the tourism industry research institute, confirmed this assumption. Generation $\mathrm{M}$ is the generation that travels the most among other age groups. They are expected to gradually spend more on tourism services compared to other age groups.

Deputy of the Industrial and Institutional Development Ministry of Tourism projects that more than $50 \%$ of the Indonesian tourism market will be millennial by 2019. This phenomenon is welcomed by turboprop aircraft manufacturer which indeed aims to reach the islands of tourism and the 'hidden paradise' located in remote locations and encourage millennial adrenaline to explore it. The potential of domestic travel interest from the demographic bonus of Indonesian and foreign millennial generation is very supportive of the development small and middle size turboprop aircraft as one of the reliable tourist transportation facilities.

d. Technological

Technological innovations have been made through the use of advanced materials such as carbon fiber composites, hybrid alloys and special coatings. Nowadays aircraft industry has applied the latest carbon fiber composite material technology on a large scale. In the past, the use of aluminum alloy (aluminum alloy) in aircraft airframes was $60-70 \%$. At present, the portion of carbon fiber composite use has reached more than $50 \%$. The challenge for the aero structure industry is the use of new material technology to produce strong, lightweight and corrosion resistant aircrafts. Another group of materials that are increasingly being used in aircraft airframes is titanium alloys. These materials are useful to reduce the weight of the aircraft so it can increase the payload of the aircraft which can be used for adding more passengers and cargo. This approach results in a $20 \%$ reduction in aircraft weight compared to conventional airframes using aluminum.

e. Environmental

Environmental issues related to the aviation world focus on noise and air pollution for the environment around the airport. Recently the issue of global warming is also becoming a topic so that the volume of $\mathrm{CO}_{2}$ emissions of aircraft into the spotlight. To meet these environmental regulations, aircraft engine manufacturers are competing to create engines that have lower noise levels, as well as exhaust emissions that meet International Civil Aviation Organization (ICAO) standards. In the long run, aircraft engine technology innovation alone is not enough to reduce $\mathrm{CO}_{2}$ emissions, so now is starting to develop new fuels that have the potential to replace fossil fuels. Therefore, aircraft operators will choose products with the use of more efficient fuels or products that 
The $1^{\text {st }}$ International Conference on Business and Engineering Management (IConBEM)

February $1^{\text {st }} 2020$, Institut Teknologi Sepuluh Nopember, Surabaya, Indonesia
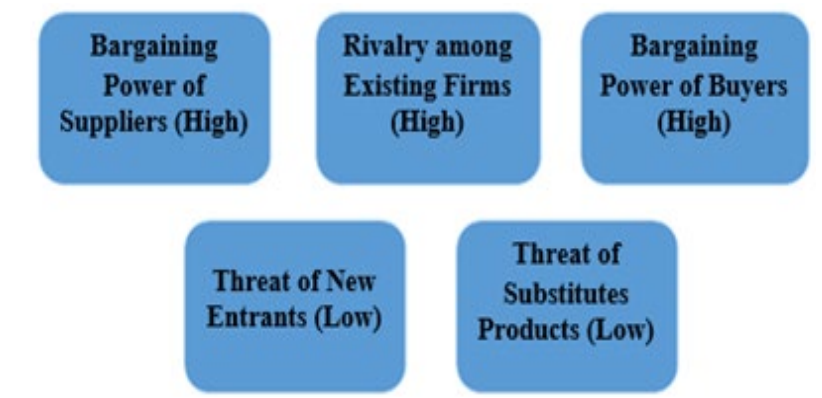

Figure 4. Conclusion of Porter's Five Analysis

use alternative fuels. Based on International Air Transport Association (IATA) data, in the long run the focus of the aerospace industry is to reduce $\mathrm{CO}_{2}$ emissions by up to $50 \%$ by 2050 , increase fuel efficiency by $1.5 \%$ per year and successfully implement carbon neutral growth so as to spur the aerospace industry to develop environmentally friendly technologies.

f. Legal

Regulations which also support aerospace industry in developing aircraft with a capacity of less than 19 seats and 50 seats are listed in the Mandate of Presidential Regulation of the Republic of Indonesia Number 28 Year 2008 Regarding National Industrial Policy, attachment page 37:

- $\quad$ Restructuring and revitalizing the aerospace industry. Developing aircraft with fewer than 30 passengers. This supports aerospace industry to develop the aircraft with capacity 19 passenger aircraft. Besides that, impact for the customers is they have to use an aircraft with maximum 30 years old. So they need either to buy new aircraft or lease from the aerospace manufacturer.

- Improve the ability and utilization of aircraft maintenance and repair facilities in the country. This encourages turboprop manufacturer's services and MRO business to increase its capabilities to design new aircraft products.

- Increase funding sources for improving the supply capabilities of the national aerospace industry. This supports manufacturers in terms of funding business development for new products.

- Develop PT DI as a center for production and R\&D and the National Aeronautics and Space Agency (LAPAN) as a center for R\&D of aerospace products.

- Developing short and medium range aircraft for various domestic and export needs. This is a motivation for PT DI to make N219 aircraft in the short range aircraft class and N245 aircraft in the medium range aircraft class.

3) Porter's 5 Forces Analysis

This model represent that high force considered as a threat because it can reduce profit while low force considered as an opportunity because it can add greater profit. The researcher can analyze the industry with three different levels of strentgh rating: high, medium, or low [2].

a. Threat of New Entrants

The aircraft industry is a very attractive and very profitable business but has a high entry barrier. The high cost of technology research and development and capital indicate that there are limitations to enter the market. It takes a very large investment to pioneer the aircraft manufacturing industry. Moreover, the average aircraft manufacturing industry which is capital and labor intensive requires the support of the local government in developing its business.

The progress of the aerospace industry is highly dependent on a country's strategic policies in protecting its business. The government sets a limitation or even prohibits new entrants into the industry, through actions such as the necessity of marketing regulations into the territory of the Republic of Indonesia. Based on those conditions, new entrants seems hard to enter aerospace industry so it can be categorized as low.

b. Threat of Substitutes Products

The development of railroad and car transport technology can threat air transport products. However, the investment and time are needed in developing modes of rail and road transportation are high. This mode of land transportation is often hampered by land acquisition efforts in making roads and railroad access that lead to conflict. This causes the position of the threat of substitution products for aircraft classified as low.

\section{c. Bargaining Power of Buyers}

Influencing factors for buyers to make decision is some buyers need financial scheme due to the high prices of aircraft. It is very complex so buyers require longer time to make decision making and larger cost for marketing. Furthermore, buyers must consider vary regulations regarding aircraft sales in each country. Not only that, the long delivery time makes buyers reluctant to buy aircraft. Customers want the aircraft purchased immediately to operate according to their target time in the market; therefore the track record of the delivery of an aircraft manufacturing industry greatly affects relations with customers and decision making to make purchases. This caused bargaining power of buyers are high.

\section{d. Bargaining Power of Suppliers}

The dependence of the domestic aircraft industry on suppliers from abroad is very high. The percentage of aircraft components originating from domestic suppliers is relatively low. This causes the domestic aircraft industry to have to wait longer for the delivery of aircraft components, which on average come from North America and Europe. Definitely it can be a negative impact on aircraft delivery time for consumers. It makes the bargaining of suppliers are high.

e. Rivalry among Existing Firms

Industry competition is very tight both in terms of the quality of production and selling prices. They have had long experience in the aerospace industry and also have a good relationship with the customers.

To get out of the market competition is very difficult because competitors have spent cost and times to bring their products penetrate in the market. Competitors in particular for commercial aircraft, have products which already establish with competitive prices, complete financing facilities and reliable product support. In addition, the mindset of the domestic market which often doubts domestic products results in a low level of market confidence in domestic-made aircraft. Therefore, the domestic aircraft industry must follow the requirements for international aviation regulation certification. It can be concluded that rivalry among existing firm is high.

Based on Figure 4, the researcher can conclude that the industry is non-attractive market since the aerospace industry is difficult to generate more profits due to the high 
The $1^{\text {st }}$ International Conference on Business and Engineering Management (IConBEM)

February $1^{\text {st }} 2020$, Institut Teknologi Sepuluh Nopember, Surabaya, Indonesia

Table 2.

Competitor Analysis of Viking Air Ltd.

\begin{tabular}{|c|c|}
\hline Key Aspect & Viking Air Ltd. \\
\hline Objectives & $\begin{array}{l}\text { To become and remain a leading, Canadian-based, global aircraft support } \\
\text { organization dedicated to the renewal and life cycle extension of a growing } \\
\text { portfolio of exceptional mission flexible aircraft. }\end{array}$ \\
\hline Assumptions & $\begin{array}{l}\text { Demand for aircraft for the short range, special mission and aerial firefighting } \\
\text { operations segments who operate in challenging conditions and harsh } \\
\text { environments }\end{array}$ \\
\hline Strategies & To have the company's sales team try and catch up with production levels \\
\hline \multirow[t]{4}{*}{$\begin{array}{l}\text { Capabilities } \\
\text { (4P) }\end{array}$} & $\begin{array}{l}\text { Product: DHC-6 Twin Otter (N219 Class); DHC-8 Dash 8-300/Q300 (N245 } \\
\text { Class) }\end{array}$ \\
\hline & Price: USD 6.5 million (DHC-6), USD 17 million (Q300) \\
\hline & Place: Sidney, British Columbia, Canada \\
\hline & $\begin{array}{l}\text { Promotion: a regular attendee and exhibitor at major aerospace tradeshows } \\
\text { and conferences worldwide, including (but not limited to) the Farnborough } \\
\text { International Airshow, Paris International Airshow, Singapore Airshow, the } \\
\text { NBAA Business and Aviation Conference \& Exhibition, and CANSEC }\end{array}$ \\
\hline
\end{tabular}

Table 3 .

SWOT Analysis of N219 and N245

\begin{tabular}{|c|c|}
\hline ANALYSIS & N219 and N245 \\
\hline Strengths (S) & $\begin{array}{l}\text { 1. Manufactured by PT DI which expert in aircraft manufacturing } \\
\text { and engineering } \\
\text { 2. High technology and good quality management system } \\
\text { 3. PT DI is the only national aircraft manufacturer in Southeast } \\
\text { Asia } \\
\text { 4. The location is reachable than buying aircraft from overseas }\end{array}$ \\
\hline Weaknesses (W) & $\begin{array}{l}\text { 1. Lack in project planning } \\
\text { 2. Delay in time delivery } \\
\text { 3. Low production capability } \\
\text { 4. Lack of confidence in using PT DI's products } \\
\text { 5. Have mindset non-commercial products }\end{array}$ \\
\hline Opportunities (O) & $\begin{array}{l}\text { 1. Increasing demand for air transportation (pioneering route, } \\
\text { commercial and tourism) } \\
\text { 2. Indonesian government support by issuing policies related } \\
\text { aviation business } \\
\text { 3. Indonesia's geographical condition is suitable for the need } \\
\text { aircraft in small and medium seat capacity. } \\
\text { 4. Low of threat new entrants }\end{array}$ \\
\hline Threats (T) & $\begin{array}{l}\text { 1. Many aircraft manufacturers and strong competitors both in } \\
\text { quality and price } \\
\text { 2. High prices due to the regulations concerning import raw } \\
\text { material taxes } \\
\text { 3. Competitors offer the same aircraft class like N } 219 \text { and N } 245 \\
\text { with competitive price } \\
\text { 4. The dominance of suppliers and the unavailability of raw } \\
\text { materials and supporting industries in Indonesia } \\
\text { 5. Regulation barriers for new aircraft }\end{array}$ \\
\hline
\end{tabular}

competitive. The stronger forces, the more limited company to be able competing and raising prices. However with this condition, the company can still enter the market and attractive since the industry still has the opportunity if seen from general environment analysis. In addition, it can be added value if the industry gain full support from the government both in regulation and financial. From the current forces, the competitive level of industry tend to be intense and high. This analysis also can help company in determining strategies to change the power of one or more forces owned by the company.

\section{4) Competitor Analysis}

If we view from the aerospace industry in Indonesia, PT DI is the only one official aviation manufacturer in Indonesia. But PT DI must be aware competitors from outside Indonesia, like Viking Air Ltd. Only Viking Air Ltd. which is the exact competitor of PT DI when viewed from the types of commercial aircraft made, namely turboprop aircraft with class 19 passengers and 56-58 passengers. Viking Air Ltd. established in 1970 as an aircraft maintenance and repair company at Victoria International Airport in Sidney, British Columbia, Canada with a focus on the seaplane and utility aircraft markets. Detail information regarding competitor analysis will be explained in Table 2 .

5) Customer Analysis

From the interviews conducted, below are the summary of data collected:

1) The operators need a new aircraft to expand and develop their business.

2) The operators need new aircraft for short and medium distance routes that are very suitable for turboprop aircraft.

3) Three of the five respondents interviewed claimed that they were less familiar with the development of new aircraft carried out by PT DI namely N219 and N245.

4) Financing scheme or dispensation program from manufacturing was needed both commercially and technically to address the shortage problem. 
The $1^{\text {st }}$ International Conference on Business and Engineering Management (IConBEM)

February $1^{\text {st }} 2020$, Institut Teknologi Sepuluh Nopember, Surabaya, Indonesia

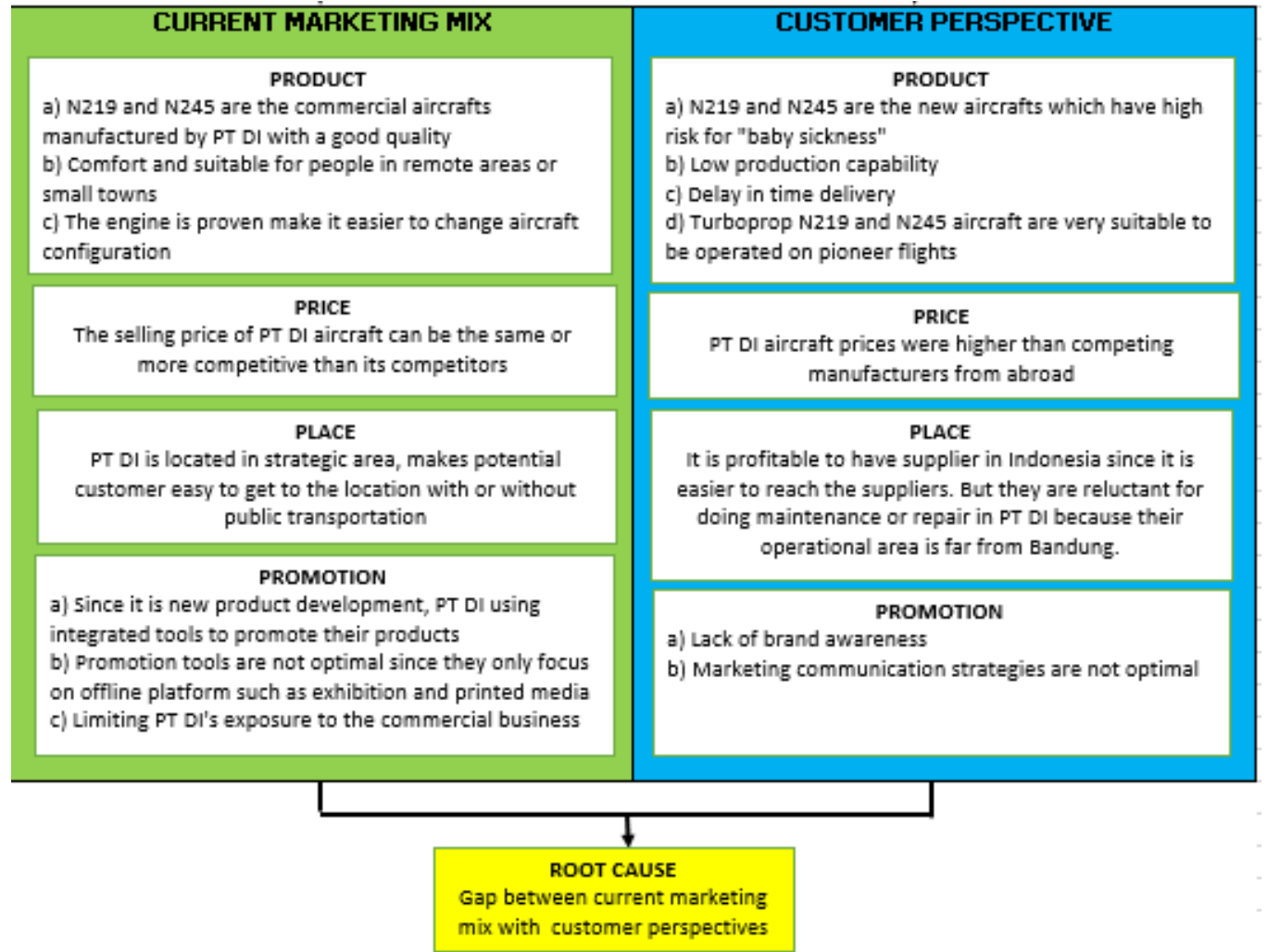

Figure 5. Root Cause Analysis

5) The important criteria for the five operators in considering an aircraft manufacturer to be their supplier are supplier provides aircraft products according to the specifications required and receives a minimum certification from the Directorate General of Civil Aviation Indonesia, have good after-sales service, and prioritized suppliers from within the country.

6) Information on aircraft prices, technical specifications and performance, delivery time, and warranty and after sales service programs are vital information in a proposal.

People who have the power to determine suppliers are company owners and shareholders.

After conducting internal and external analysis, the researcher finds the main problem and what factors which underlying the problem as shown in figure 5.

From analysis above, it can be seen that the main problem faced by PT DI is decreasing percentage of aircraft sales. There is gap between current marketing mix with customer perspectives related N219 and N245 aircrafts. It can be concluded that information from marketing existing marketing are not optimal and effective. In summary, the researcher try to propose marketing mix in order to sustain their business in defense industry.

\section{Proposed Marketing Mix}

\section{a. Product}

The aircrafts could be have shortage as the risk of new product development. Improvements to the design of technical configurations is still ongoing from the prototype to the initial serial production. But in the real condition, specifications and technical performance at the initial serial production are not exactly the same as the expected design.
Another problems in the augmented product level is related with time delivery. PT DI tend to exceed the delivery of time which is different with the agreement in the sales contract. It is caused by the low production capacity compared to the number of aircraft orders. Therefore, PT DI need strategies to overcome those matters as follows:

- Providing Customize Aircraft Configuration

As a new product development the PT DI's commercial aircraft should fulfill the expectation of aircraft configuration from its potential customers. The characteristics of customers requirement may be different each other. It is because the utilization of aircraft operation on various route in Indonesia's region that also has unique or special requirement.

- Assigning technicians to monitor the aircrafts

Specifically assigning some dedicated technicians to monitor the progress of the aircraft that has been delivered and take responsive actions if there are any trouble by coordinating with PT DI's central engineering.

- $\quad$ Replacing the aircrafts if customer having problem with shortage

If customers complain with the shortage and it cannot be accepted according to the technical standards expected by the customer PT DI is willing to replace or exchange aircraft that have been delivered to the customer with the new aircraft which have been improved.

- Extending the warranty program

Provides a longer period of warranty program for the commercial aircraft.

- Providing resale value guarantee

This privilege can be done if the condition of the aircraft is good and meet the strict standards in aircraft maintenance. 
The $1^{\text {st }}$ International Conference on Business and Engineering Management (IConBEM)

February $1^{\text {st }} 2020$, Institut Teknologi Sepuluh Nopember, Surabaya, Indonesia

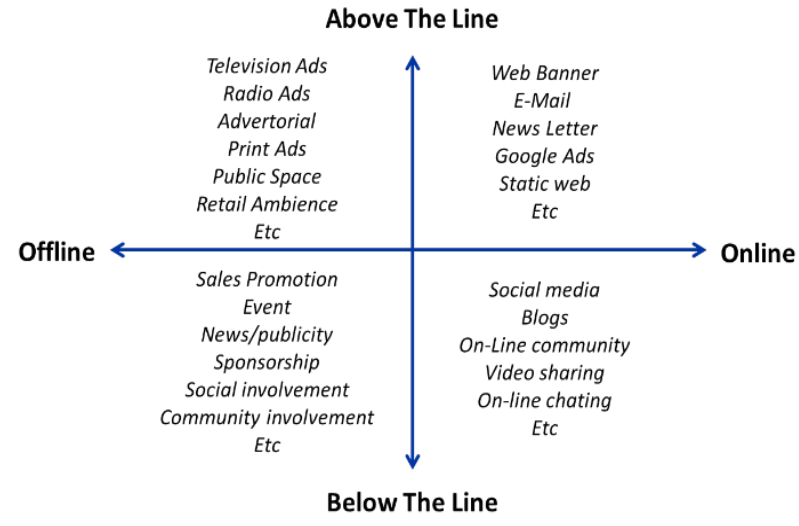

Figure 6. Marketing Communication Channel

For example if the customer do the after sales service in PT DI periodically.

- Increasing production capacity

Expansion of production facilities by adding a special production line for commercial civil aircraft that is different from military aircraft as the current product and apply manufacturing robotics to speed up the production process.

b. Price

The high selling price of N219 and N245 can be solved by propose to the Ministry of Finance through the Ministry of Industry and the Ministry of SOEs to get the same tax on domestic aircraft sales, both imported and from domestic producers, so they will have same position.

The next solution is providing customer financing. Financing support for buyers is one of the main requirements in purchasing commercial aircraft and this is also a criterion in selecting potential suppliers by customers. It is highly recommended so PT DI can compete with other competitors who have already financing scheme with their partners. It is a typically characteristic from commercial aircraft business because military aircraft business do not need financing scheme which already have a defense budget like cash provided by each government.

c. Place

The existence of PT DI which is the only aircraft manufacturer in the country is not only limited to the product but also to the sustainability of the product or called as after sales service.

PT DI needs to provide product support including the provision of MRO (Maintenance, Repair \& Overhaul) facilities in the closest location to the operational area. N219 and N245 aircraft are used on pioneer flights or airport with short runways, which are often found outside the Java island like mostly in Eastern Indonesia, Papua, Ambon, Nusa Tenggara, Kalimantan and Sulawesi. Customers need MRO facilities that are close to the operational area to save high service costs if they have to fly to PT DI's production center in Bandung or bring technicians from Bandung to their operating areas.

\section{d. Promotion}

PT DI needs integrated marketing communication in order to deliver the value propositions so the customer can have the same perceptions as the expected by the company. The choice of communication tools must be clear and fit with the objective.

N219 and N245 are commercial aircrafts and also new development products by PT DI. It has to be promoted so people can recognize the product easily. Marketing communication channel is consisted of above the line and below the line. Above the line media also known as mass media is marketing through media like radio, television, print Ads, e-mail, or newsletter. Target audience of above the line is more impersonal rather than below the line. In contrast, below the line is media promotion with personal target using exhibitions, sales promotion or public relations.

The proposed marketing strategy, at the first launching, it is recommended for PT DI to choose above the line media since it is more effective to reach wider customer. PT DI can use media such as magazines, newspapers, public space, static web, etc.

\section{CONCLUSION}

PT. Dirgantara Indonesia (PT DI) as the only aircraft manufacturer in Indonesia facing problem decreasing percentage of the aircraft sales. In order to overcome this issue, PT DI need to seek another strategy particularly shifting the market from military to commercial market. Since it is their new product development, PT DI need strategy to enter the commercial market and solve the gap between current marketing mix with the customer perspective towards N219 and N245 aircrafts. The proposed marketing mix recommended for PT DI as follows:

1. Provide customize aircraft configuration, assign technicians, replace the shortage aircraft with the new one, extend the warranty period, provide resale value guarantee, and increase production capacity for the product.

2. Propose new regulation related tax policy to the Ministry of Finance and provide financing scheme for the customer.

3. Placing new facility for MRO at the closest location of customer's operational area.

4. Choose above the line media at the first launching for wider target and then using below the line media to reach the niche market.

\section{REFERENCES}

[1] P. Kotler and G. Armstrong, Principles of Marketing, 15th ed. Boston, Massachusetts: Pearson, 2014.

[2] T. L. Wheelen and J. D. Hunger, Strategic Management and Business Policy: Toward Global Sustainability. Upper Saddle River, New Jersey: Pearson Education, 2012. 